\title{
PERAN PERHATIAN ORANG TUA TERHADAP PROSES BELAJAR ANAK DARI RUMAH PADA MASA PANDEMI COVID-19
}

\author{
Ummu Jauharin Farda, Anas Rohman dan Achmad Mustofa \\ Fakultas Agama Islam \\ Universitas Wahid Hasyim Semarang
}

Email: jaufaummu91@gmail.com anasrohman@unwahas.ac.id achmadmustofa333@gmail.com

\begin{abstract}
Abstrack: The role of parental attention in supervising the child's learning process at home during the Covid-19 pandemic, parents become teachers automatically, accompany children's learning, and others. facilitate internet access. Inhibiting factors in the child's learning process at home during the Covid-19 pandemic include: limited internet access or quotas, not having a lektop or gaadged, lack of parental attention, difficulty in understanding lessons due to the online learning process, while supporting factors include the availability of tools online learning, the existence of student interest in the online learning process, the motivation of parents and the healthy condition of students. This research method is a field research or field research. Research Subjects, the subjects to be studied are school children in RT 002 RW 001, Sekayu Village, Semarang City. Analysis of the data used is non-statistical analysis but with qualitative analysis. The condition of the Covid-19 pandemic in RT $002 R W 001$, Sekayu Village, Semarang City, from an economic point of view, is not very influential but from an educational perspective it shows that it is very influential because of the readiness of schools and students to participate in online learning.

Keywords: Parental Attention, Learning Process, Covid pandemic
\end{abstract}

\begin{abstract}
Abstrak: Peran perhatian orang tua dalam mengawasi proses belajar anak di rumah pada masa pandemi Covid-19 orang tua menjadi guru secara otomatis, menemani belajar anak, membantu menjelaskan materi pelajaran kepada anak dan lain-lain, menfasilitasi akses internet. Faktor penghambat dalam terhadap proses belajar anak di rumah pada masa pandemi Covid-19 diantaranya: keterbatasan akses internet atau kuota, tidak memiliki lektop atau gaadged, kurangnya Perhatian orang tua, kesulitan dalam memahami pelajaran karena proses belajar daring, sedangkan faktor pendukung di antranya tersedianya alat belajar daring, adanya minat siswa dalam proses belajar daring, adanya motivasi dari orang tua dan kondisi siswa yang sehat. Metode penelitian ini merupakan riset lapangan atau field research. Subjek yang akan diteliti adalah anak-anak Sekolah di RT 002 RW 001 Kelurahan Sekayu Kota Semarang. Analisis data yang digunakan adalah analisis non statistik melainkan dengan analisis kualitatif. Kondisi pandemi Covid-19 di RT 002 RW 001 Kelurahan Sekayu Kota Semarang dilihat dari sisi ekonomi tidak begitu berpengaruh tetapi di lihat dari segi pendidikan ini menunjukkan sangat mempengaruhi karena kesiapan dari sekolah maupun dari siswa untuk mengikuti pembelajaran daring.
\end{abstract}

Kata Kunci : Perhatian Orang Tua, Proses Belajar, Pandemi covid 


\section{A. PENDAHULUAN}

Keberhasilan belajar anak, sangat ditentukan oleh beberapa faktor, antara lain adanya dorongan atau motivasi, baik secara intrinsik maupun ekstrinsik. Dalam kaitannya dengan yang disebutkan terakhir ini, motivasi orang tua sangat menentukan. Di samping itu keterikatan biologis dan psikologis antara orang tua dan anaknya mempunyai implikasi tanggung jawab secara moral bagi orang tua untuk senantiasa memperhatikan pendidikan anaknya.

Ada beberapa faktor yang dapat mempengaruhi perkembangan kecerdasan anak yaitu makan, waktu tidur, rasa trauma, kegiatan fisik, ikatan dengan orang tua dan kemampuan untuk belajar. ${ }^{1}$ Pada tanggal 20 Februari 2020international committee on taxonomy of viruses (ICTV) mendeklarasikan bahwa nCoV-2019 menjadi nama resmi dari severe acute respiratory syndrome coronavirus 2 (SARS-CoV-2), dan pada hari yang sama WHO mendeklarasikan SARS-CoV-2 nama resmi adalah corona virus disease 2019 (COVID 19). ${ }^{2}$

Virus ini sangat mudah tertular melaui cairan yang dihasilkan dari bersin, batuk, dan berbicara. Cara penyebaran virus Corona juga bisa melalui kontak jarak dekat yang melibatkan sentuhan secara langsung seperti berjabatan tangan. Selain itu, virus ini juga bisa menyebar jika seseorang bersentuhan dengan permukaan benda yang telah terpapar virus corona. Penyebab virus corona bisa menyebar ke seluruh dunia adalah karena penderita virus ini tampak dalam keadaan prima dan tidak memiliki gejala yang kemudian bisa menularkan ke orang disekitarnya.

Wabah yang diakibatkan virus bernama corona ini membawa dampak bagi seluruh aspek kehidupan dalam masyarakat, khususnya pendidikan. Aktivitas belajar mengajar yang biasa dilakukan secara langsung harus dihentikan dan digantikan dengan belajar secara daring.Seperti sekarang ini khususnya dalam dunia pendidikan dan latihan penempatan teknologi komunikasi ini sangat

\footnotetext{
${ }^{1}$ Akademi orangtua Indonesia surakarta (Aorta), Buku Pintar Orang Tua, Solo: Tiga Serangkai, 2018, hlm.72

${ }^{2}$ Komisi kesehlmatan nasional RRC administrasi Nasional pengobatan Tradisional RRC, Panduan menghlmadapi penyakit virus corona 2019 model RRC
} 
mendukung untuk mengembangkan suatu inovasi, khususnya yang berhubungan dengan; (a) virtual learning (b) distance learning (c) mailing and telephon (d) komputer medited comunication (e komputer based traning (f) e-learning (g) tutorial elektronic. Sebagai contoh untuk kepentingan teleconfenc ini, maka faktor dari penguasaan terhadap teknologi komunikasi merupakan prioritas yang harus difikirkan. ${ }^{3}$

Berkembangnya teknologi informasi dan komunikasi, khususnya mengenai dampak dalam transformasi pesan, maka proses pembelajaran pun mengalami perubahan. Adanya media internet memudahkan warga belajar untuk mengakses ke bagian sumber informasi, termasuk ke halam web. Melalui halaman web ini, maka warga dapat belajar mentransformasikan informasinya ke pada orang lain sehingga membentuk suatu jaringan atau komunitas belajar yang dikenal dengan virtual learning. ${ }^{4}$

Menurut surat edaran Sekretaris Jendral Kemendikbud nomer 15 tahun 2020 tentang pedoman penyelenggaraan belajar dari rumah dalam masa darurat penyebaran corona virus disease (Covid-19). Tujuan pelaksanaan belajar dari rumah(BDR) selama darurat Covid-19 yaitu: ${ }^{5}$

1. Memastikan pemenuhan hak peserta didik untuk mendapatkan layanan pendidikan selama darurat Covid-19.

2. Melindungi warga satuan pendidikan dari dampak buruk Covid-19.

3. Mencegah penyebaran dan penularan Covid-19 di satuan pendidikan

4. Memastikan pemenuhan dukungan psikososial bagi pendidik, peserta didik dan orang tua/wali.

Menurut Kepala Dinas Pendidikan Kota Semarang Provinsi Jawa Tengah ,Gunawan Saptogiri, perpanjangan masa belajar dari rumah untuk jenjang SD, SMP, maupun Sekolah Non Formal (SNF) itu masih merujuk pada surat yang edaran bernomor: B/3606/440/IV/2020 tentang Layanan Penyelenggaraan

\footnotetext{
${ }^{3}$ Deni Darmawan, Inovasi Pendidikan (Pendekatan praktik teknologi multi media dan pembelajaran online), Bandung: Pt. Permaja Rosdakarya, 2012, hlm. 83

${ }^{4}$ Ibid, hlm. 85

${ }^{5}$ Sekretaris Jendral Kemendikbud nomer 15 tahlmun 2020 tentang pedoman penyelenggaraan belajar dari rumahlm dalam masa darurat penyebaran corona virus disease (Covid-19), Jakarta, 2020, hlm. 9
} 
Pendidikan dalam Rangka Pencegahan Penularan dan Penyebaran Corona Virus Disease (Covid-19) di Kota Semarang. ${ }^{6}$

Pendidikan dalam lingkungan keluarga adalah orang tua. Hal ini disebabkan karena secara alami anak-anak pada masaawal kehidupannya beradadi tengahtengah ayah dan ibunya. Maka dari merekalah anak mulai mengenal pendidikannya. Dasar pandangan hidup, sikap hidup dan keterampilan hidup banyak tertanam sejak berada di tengah orang tuanya. ${ }^{7}$

Kegiatan belajar anak di kelurahan sekayu di masa pandemi Covid-19 sangat berbeda tidak seperti biasanya, meskipun situasinya berada di jantung kota tetapi masih ada sebagian ank-anak yang kluyuran. Sekayu adalah suatu kampung yang mana sebagian pendidikan orang tuanya masih rendah. Kebanyakan orang tua merekaadalah pekerja, anak-anaknya berada dirumah bahkan setiap harinya lepas dari pantauan sehingga kuranglah perhatiandari orang tuanya. Minat anak saat proses belajar dari rumah masih kurang karena mereka belum terbiasa dengan pembelajaran online.Tidak semua anak memiliki laptop atau handphoneandroid yang canggih, perlu adanya pulsa atau kuota atau wifi untuk dapat mengkoneksikan dengan internet sehingga anak-anak tidak dapat mengikuti pembelajaran dengan maksimal.

Berdasarkan Preliminary research wawancara yang telah dilakukan oleh peneliti kepada siswa SMP kelas dua dengan pertanyaan bagaimana kamu dapat mengikuti proses belajar dengan sistem online dari rumah, dia menjawab:

"Saya kesulitan mengikuti proses belajar dengan Online karena bapak atau ibu juga tidak tahu caranya seperti apa dan akhirnya saya meminta bantuan kepada tetangga saya dan terkadang kuota internetnya habis sehingga tidak jadi ikut proses belajar". 8

Melihat hasil Preliminary research yang peneliti lakukan menunjukkan bahwa perhatian orang tua sangatlah diperlukan dan sebagai orang tua harus selalu

\footnotetext{
${ }^{6}$ hlmttps://jateng.tribunnews.com/2020/05/04/dinas-pendidikan-kota-semarangperpanjang-masa-belajar-di-rumahlm-hlmingga-batas-waktu-tak-ditentukan

${ }^{7}$ Ali mufron, Ilmu Pendidikan Islam, Yogjakarta: aura pustaka,2013, hlm. 34

${ }^{8}$ Muhlmammad Isnul afifi, siswa SMP kelas II , di taman, pada hari jum'at tanggal 05 Juni 2020
} 
belajar mengikuti perkembangan teknologi agar selalu dapat mendampingi anaknya dalam kegiatan belajar. Berdasarkan uraian di atas maka peneliti tertarik untuk mengadakan penelitian dengan judul "Peran Perhatian Orang Tua Terhadap Proses Belajar Anak dari Rumah pada Masa Pandemi Covid-19 di Rt. 002 Rw. 001 Kelurahan Sekayu Kota Semarang”.

\section{B. METODE ANALISIS DATA}

Analisis data merupakan upaya mencari dan menata secara sistematis catatan hasil observasi, wawancara dan lainnya untuk meningkatkan pemahaman peneliti dan mengkajinya sebagai temuan bagi orang lain. Analisis data yang digunakan adalah analisis non statistik melainkan dengan analisis kualitatif. Penelitian ini langsung terjun ke lapangan, mempelajari, menganalisa, menafsirkan, dan menarik kesimpulan dari fenomena yang ada di lapangan. Langkah-langkah dalam menganalisis data pada penelitian kualitatif deskriptif adalah sebagai berikut:

Untuk mendapatkan data di lapangan, peneliti melakukan observasi, wawancara dan dokumentasi. Data yang diperoleh berupa catatan lapangan mengenai obyek yang diteliti. ${ }^{9}$

\section{Data Reduction (Reduksi Data)}

Mereduksi data yang berati merangkum, memilih hal-hal yang pokok, menfokuskan pada hal-hal yang penting, dicari tema dan polanya dan membuang yang tidak perlu. ${ }^{10}$

2. Data Display (penyajian data)

Penyajian data yang dimaksudkan agar semua data yang diperoleh di lapangan yang berupa data hasil observasi, wawancara, dan dokumentasi kemudian dianalisis sehingga menghasilkan deskriptif implementasi guru dalam meningkatkan mutu pembelajaran. Dalam penelitian kualitatif, hlm. 30 .

${ }^{9}$ Noeng Muhlmadjir, Metodologi Penelitian Kualitatif, Yogyakarta: Rake Sarasin, 2016, ${ }^{10}$ Ibid, hlm.31. 
penyajian data bisa dilakukan dalam bentuk uraian singkat, bagan, hubungan antar kategori dan sejenisnya.

3. Penarikan Kesimpulan

Menarik kesimpulan adalah proses terprnting dan terakhir dilakuakan dalam analisis data kualitatif. Peneliti mencari makna dari data yang diperolehnya, untuk itu berusaha mencari pola, model, tema, hubungan, persamaan, hal-hal yang sering muncul, hipotesis dan sebagainya. ${ }^{11}$ Kesimpulan yang diambil harus bisa diuji kebenarannya dan kecocokannya sehingga menunjukkan keadaan yang sebenarnya. Verifikasi dapat dilakukan dengan singkat yaitu dengan cara mengumpulkan data baru.

\section{PEMBAHASAN}

1. Perhatian Orang Tua Terhadap Proses Belajar Anak Dari Rumah Pada Masa Pandemi Covid-19

Perhatian (Inggris: attention) adalah salah satu dari sekian banyak gejala psikologis pada diri manusia. Perhatian terjadi aktivitas kejiwaan yang melibatkan otak dan indera. Proses belajar mengajar akan senantiasa merupakan proses interaksi antara dua unsur manusiawi, yakni siswa sebagai pihak yang belajar dan guru sebagai pihak yang mengajar, dengan siswa sebagai subyek pokoknya. Interaksi belajar mengajar adalah hubungan aktif dua arah antara pendidik dengan peserta didik dalam suatu kegiatan belajar.

\section{Perhatian Orang Tua Terhadap Proses Belajar Anak Dari Rumah Pada} Masa Pandemi Covid-19 Di Rt 002 Rw 001 Kelurahan Sekayu Kota Semarang

Rt. 002 Rw. 001 Kelurahan Sekayu Kota Semarang berpusat di tengah kota yang di kooardinasi orang seorang RT yang bernama Edi suyanto beliau sudah 2,5 periode. Setiap periode 3 tahun menjabat sebagai ketua RT. Seperti yang di tuturkan oleh bapak RT. Bapak sudah menjabat berapa lama 7,5 tahun $(2,5 \text { periode })^{\prime \prime 12}$. Berdasarkan keterangan Bapak RT bahwa Bapak RT sudah

\footnotetext{
${ }^{11}$ Ibid, hlm. 63.

${ }^{12}$ Edi Suyanto, Sebagai Ketua RT, wawancara pada hari Rabu 15 Juli 2020
} 
menjabat 7,5 tahun artinya 2,5 periode karena setiap periode 3 tahunjabatan sebagai RT. Selama Bapak Edi suyanto menjabat jumlah KK atau kepala keluarga di Rt.002 Rw.001 Kelurahan Sekayu Kota Semarang. Seperti yang di sampaikan oleh Bapak RT. 55 Kepala Keluarga"13 Berdasarkan keterangan Bapak RT bahwa jumlah KK sampai saat ini adalah 55 kepala keluarga. Banyak anak-anak yang masih sekolah di Rt.002 Rw.001 Kelurahan Sekayu Kota Semarang. Seperti yang di sampaikan oleh Bapak RT. "Sekitar $15^{14}$

Adanya surat edaran belajar di rumah pada saat ini anak- anak belajar kurang maksimal. Kurangnya maksimal ini akan mempengaruhi hasil belajar anak. Hasil belajar anak di rumah tidaklah sebagus belajar di sekolah yang langsung didampingi oleh guru mata pelajaran. Ketika terjadi pandemi seperti saat ini orang tua sekaligus menjadi guru memang kurang efektif di era ini. Ini seperti yang terjadi pada anak-anak di Rt.002 Rw.001 Kelurahan Sekayu Kota Semarang dalam mengikuti proses belajar dirumah seperti yang di sampaikan oleh orang tua siswa. Bahwa "Kurang efektif karena belum terbiasa"15

Berdasarkan keterangan dari orang tua siswa bahwa dalam proses pembelajaran yang di lakukan dirumah kurang efektif karena belum terbiasa dalam kegiatan belajar dimasa pandemic. Masa pandemi apa pun perintah dan anjuran pemerintah harus diikuti, dengan mengikuti anjuran ini dan melakukan protokol kesehatan bisa mengurangi penularan Covid-19 di negara kita. Masyarakat disini bisa menjaga dan bisa menyesuaikan dan juga tidak panik dengan aturan ini semua bisa berjalan lancar sesuai harapan sekolah maupun harapan guru materi. Sesuai dengan kata bapak RT bahwa warganya tidak begitu panik masih tergolong kondusif dan bisa menyesuaikan dengan adanya pandemic ini. Keadaan warga di masa pandemi covid-19 di Rt.002 Rw.001 Kelurahan Sekayu Kota Semarang di sampaikan oleh bapak RT. "Tenang, tidak begitu panik, masih tergolong kondusif". ${ }^{16}$

13 Edi Suyanto, Sebagai Ketua RT, wawancara pada hari Rabu 15 Juli 2020

14 Edi Suyanto, Sebagai Ketua RT, wawancara pada hari Rabu 15 Juli 2020

${ }^{15}$ Suroto, Sebagai Orang tua siswa, wawancara pada hari Rabu 15 Juli 2020

${ }^{16}$ Edi Suyanto, Sebagai Ketua RT, wawancara pada hari Rabu 15 Juli 2020 
Melihat kondisi belajar anak di Rt.002 Rw.001 Kelurahan Sekayu Kota Semarang setelah penetapan belajar dari rumah oleh pemerintah di masa pandemi covid-19 seperti yang di sampaikan orang tua siswa "Menurun drastis" ${ }^{17}$ Kondisi belajar anak-anak disini sangat menurun drastis dengan adanya kebijakan belajar dirumah. Hasil tugas yang diberikan oleh guru kepada siswa sangat merepotkan orang tua. Hasil yang dikerjakan anak-anak saat belajar di rumah kurang begitu maksimal.

Adanya belajar online anak- anak belajar setiap harinya dengan smartphone atau gadged yang ada guna mengakses materi dan penjelasan dari guru. Anak- anak bisa mendapatkan penjelasan maupun keterangan melalui gadget mereka. Orang tua harus melengakapi dengan paket data agar bisa mengakses materi ataupun penjelasan dari guru. Ini tidak menjadi masalah untuk masyrakat di rt 002 rw 001 kelurahan sekayu kota semarang karena menurut penjelasan bapak RT. tingkat ekonomi warga di masa pandemi covid19 di Rt.002 Rw.001 Kelurahan Sekayu Kota Semarang. "Tidak begitu berpengaruh yang signifikan, di tambah di kampung di support ada lumbung pangan"18

\section{Peran Perhatian Orang Tua Dalam Mengawasi Proses Belajar Anak di}

\section{Rumah Pada Masa Pandemi Covid-19 Di Rt 002 Rw 001 Kelurahan Sekayu Kota Semarang}

Era Covid-19 anak -anak Sekayau melakukan banyak kegiatan di rumah, seperti yang telah di tutuerrkan bapak RT dalam wawancara saya anak -anak di sini melakukan kegiatan yang positif saat mengisi kegiatan di rumah. Banyak dari mereka mengisi kegiatannya dengan main bareng seperti bersepeda, lari- lari, jalan-jalan maupun mainan yang lainnya. Untuk menghabiskan waktu anak -anak banyak waktu bermainnya dari pada belajar. Namanya juga anak-anak Belajar di rumah dibilang juga hari libur walaupun perintah guru sudah jelas. Waktu belajar dirumah sangatlah singkat karena harus menunggu tugas dari sekolahan. Seperti yang di sampaikan oleh bapak

\footnotetext{
${ }^{17}$ Suroto, Sebagai Orang tua siswa, wawancara pada hari Rabu 15 Juli 2020

${ }^{18}$ Edi Suyanto, Sebagai Ketua RT, wawancara pada hari Rabu 15 Juli 2020
} 
RT. kegiatan anak-anak di masa pandemi covid-19 di Rt.002 Rw.001 Kelurahan Sekayu Kota Semarang "Melakukan kegiatan positif, dengan bermain, salah satunya bersepedaan, lari-lari." ${ }^{19}$

Pada Era pandemik Covid-19 ini banyak orang tua yang belum bisa menyesuaikan, karena sangat mendadak. Keadaan yang tiba- tiba ini sangat merepotkan orang tua apa lagi harus mendampingi anak belajar pada saat jam bekerja. Hal semacam inilah yang menyebabkan orang tua kaget dan tahu bagaimana rasanya mengaja anaknya sendiri dan ikut perihatin dengan para guru yang mengajar di sekolah selama ini. Kejadian ini juga menyadarkan orang tua dengan sikap anaknya terhadap guru, kepala sekolah maupun staf yang berkerja dalam Lembaga Pendidikan tempat anaknya menuntut ilmu. Orang tua sekaligus guru bagi anaknya sangat kerepotan dengan hal semacam ini.seperti penuturan daribapak RT bahwa orang tua yang mendampingi anaknya belajar di masa pandemi covid-19 di Rt.002 Rw.001 Kelurahan Sekayu Kota Semarang. "Orang tua banyak yang belum terbiasa, karna merasa tidak maksimal belajar dari rumah."20

Banyak dari mereka merasa kurang puas dengan adanya belajar dari rumah, belajar dari rumah ini bertujuan bukan untuk membebani orang tua untuk menhjadi guru secatra tiba- tiba melainkan untuk mengawasi dann juga ikut serta dalam mencegah penyebarab penyakit Covid-19. Dengan adanya penyakit Covid-19 ini mau tidak mau orang tua harus siap dan sigap mengemban tugas menjadi jguru di rumah masing- masing. Anak anak juga harus bisa menerima bahwa gurunya adalah orang tuanya sendiri. Tugas apapun yang ada harus di selesaikan. Materi apapun harus dipelajari dan difahami oleh ansaak- anak dengan bimbingan dan pengawasan orang tua. Adapaun bapak RT menyampaikan bahwa saran warganya khusunya orang tua dalam proses belajar dari rumah di masa pandemi covid-19 di Rt.002

\footnotetext{
${ }^{19}$ Edi Suyanto, Sebagai Ketua RT, wawancara pada hari Rabu 15 Juli 2020

${ }^{20}$ Ibid
} 
Rw.001Kelurahan Sekayu Kota Semarang “ Orang tua harus mendampingi dalam proses belajar anak"21

Situasi belajar di kampung ini sangatlah kondusif, tenang, tidak begitu panik, kondisi semacam ini sangatlah bagus karena tidak terpaku dengan satu keadaan.artinya masyarakat masih bisa bertindak secara cepat dan tidak bingung dalam menghadapi ini.

Adanya belajar online anak- anak belajar setiap harinya dengan smarphone atau gadged yang ada guna mengakses materi dan penjelasan dari guru. Anak- anak bisa mendapatkan penjelasan maupun keterangan melalui gadget mereka. Orang tua harus melengakapi dengan paket data agar bisa mengakses materi ataupun penjelasan dari guru. Menurut bapak RT peran orang tua dalam proses belajar dari rumah di masa pandemi covid-19 di Rt.002 Rw.001 Kelurahan Sekayu Kota Semarang “Banyak yang kurang puas dalam proses belajar daring (dalam jaringan) ${ }^{, 22}$

Setiap anak harus memiliki gadget untuk pembelajaran online atau daring di Rt.002 Rw.001 Kelurahan Sekayu Kota Semarang seperti yang disampaikan oleh orang tua siswa bapak atau ibu mempunyai gadget untuk dapat mengikuti belajar online di masa pandemi covid-19.

4. Analisis peran perhatian orang tua terhadap proses belajar anak dari rumah pada masa pandemi covid-19 di rt 002 rw 001 kelurahan sekayu kota semarang

a. Analisis Kondisi Pandemi Covid-19 di Rt 002 Rw 001 Kelurahan Sekayu Kota Semarang

Pandemi merupakan penyakit yang menyebar secara global meliputi area geografis yang luas. Penyebaranya sangat cepat, Orang dapat tertular Covid-19 dari orang lain yang terinfeksi virus ini. Covid-19 dapat menyebar terutama dari orang ke orang melalui percikan-percikan dari hidung atau mulut yang keluar saat orang yang terinfeksi Covid-19 batuk, bersin atau berbicara. Setiap orang dapat terinfeksi dengan menyentuh

\footnotetext{
${ }^{21}$ Edi Suyanto, Sebagai Ketua RT, wawancara pada hari Rabu 15 Juli 2020

${ }^{22}$ Ibid
} 
benda atau permukaan tersebut, kemudian menyentuh mata, hidung, atau mulut mereka. Inilah sebabnya penting untuk mencuci tangan secara teratur dengan sabun dan air bersih mengalir, atau membersihkannya dengan cairan antiseptik berbahan dasar alkohol. WHO terus mengkaji perkembangan penelitian tentang cara penyebaran Covid-19 dan akan menyampaikan temuan-temuan terbaru. ${ }^{23}$

Sebagian besar (sekitar 80\%) orang yang terinfeksi berhasil pulih tanpa perlu perawatan khusus. Sekitar 1 dari 5 orang yang terinfeksi Covid-19 menderita sakit parah dan kesulitan bernapas. Orang-orang lanjut usia (lansia) dan orang-orang dengan kondisi medis penyerta seperti tekanan darah tinggi, gangguan jantung dan paru-paru, diabetes, atau kanker memiliki kemungkinan lebih besar mengalami sakit lebih serius. Namun, siapa pun dapat terinfeksi Covid-19 dan mengalami sakit yang serius. Gejala-gejala Covid-19 yang paling umum adalah demam, batuk kering, dan rasa lelah. Gejala lainnya yang lebih jarang dan mungkin dialami beberapa pasien meliputi rasa nyeri dan sakit, hidung tersumbat, sakit kepala, konjungtivitis, sakit tenggorokan, diare, kehilangan indera rasa atau penciuman, ruam pada kulit, atau perubahan warna jari tangan atau kaki. Gejala-gejala yang dialami biasanya bersifat ringan dan muncul secara bertahap. Beberapa orang menjadi terinfeksi tetapi hanya memiliki gejala ringan.

Kondisi pandemik seperti ini semua kegiatan masyrakat terhenti baik itu yang bekerja, sekolah, atau aktivitasyang lain dimana itu menimbulkan kerumunan untuk memutus mata rantai virus Covid-19. Namun berbeda dengan kondisi warga di masa pandemi covid-19 di Rt.002 Rw.001Kelurahan Sekayu Kota Semarang seperti yang di tuturkan oleh bapak RT. "Tenang, tidak begitu panic, masih tergolong kondusif."24

Sekayu memiliki lumbung pangan ini merupakan kas RT yang didapat dari iuran dari warga di setiap rumah mengisi kotak yang telah di

\footnotetext{
${ }^{23}$ https://www.who.int/indonesia/news/novel-coronavirus/qa-for-public

${ }^{24}$ Edi Suyanto, Sebagai Ketua RT, wawancara pada hari Rabu 15 Juli 2020
} 
sediakan oleh RT setiap malamnya, besarnya iuran sebesar Rp. 500,00 nanti akan ada petugas yang mengambilnya . Di Rt.002 Rw.001 Kelurahan Sekayu ada 55 KK (kepala keluarga) bila iuran Rp.500 X 55 KK maka jumlah uang yang di peroleh setiap malamnya Rp. 27.500 X 30 hari jadi selama sebulan Rp.825.000 dan selama bapak lurah menjabat belum di gunakan berdasarkan hasil lumbung pangan yang cukup besar maka pandemi Covid-19 tidak berpengaruh signifikan.

Orang dapat tertular Covid-19 dari orang lain yang terinfeksi virus ini. Covid-19 dapat menyebar terutama dari orang ke orang melalui percikan-percikan dari hidung atau mulut yang keluar saat orang yang terinfeksi Covid-19 batuk, bersin atau berbicara. Percikan-percikan ini relatif berat, perjalanannya tidak jauh dan jatuh ke tanah dengan cepat. Orang dapat terinfeksi Covid-19 jika menghirup percikan orang yang terinfeksi virus ini. Oleh karena itu, penting bagi kita untuk menjaga jarak minimal satu meter dari orang lain. Percikan-percikan ini dapat menempel di benda dan permukaan lainnya di sekitar orang seperti meja, gagang pintu, dan pegangan tangan. Orang dapat terinfeksi dengan menyentuh benda atau permukaan tersebut, kemudian menyentuh mata, hidung, atau mulut mereka. Inilah sebabnya penting untuk mencuci tangan secara teratur dengan sabun dan air bersih mengalir, atau membersihkannya dengan cairan antiseptik berbahan dasar alkohol. WHO terus mengkaji perkembangan penelitian tentang cara penyebaran Covid-19 dan akan menyampaikan temuan-temuan terbaru. ${ }^{25}$

Terjadinya pandemik Covid-19 sangat berpengaruh pada kondisi anak-anak di Rt. 002 Rw.001 Kelurahan Sekayu dengan adanya surat edaran dari kementrian pendidikan bahwa anak-anak belajar dirumah selama darurat Covid-19 di laksanakan dengan tetap memperhatikan protocol kesehatan dan belajar dari rumah melalui pembelajarn jarak jauh daring dan/ luring dilaksanakan sesuai dengan pedoman penyelenggaran belajar dari rumah. Seperti yang di sampaikan oleh orang tua siswa bahwa

${ }^{25}$ https://www.who.int/indonesia/news/novel-coronavirus/qa-for-public 
kondisi belajar anak setelah penetapan belajar dari rumah oleh pemerintah di masa pandemi covid-19 "Menurun derastis ${ }^{26}$

Ini menunjukkan bahwa kondisi pandemi covid-19 di rt 002 rw 001 Kelurahan Sekayu Kota Semarang dilihat dari ekonomi tidak begitu berpengaruh tetapi di lihat dari segi pendidikan ini menunjukkan sangat mempengaruhi karena kesiapan dari sekolah maupun dari siswa untuk mengikuti pembelajaran daring.

\section{b. Analisis Peran Perhatian Orang Tua Dalam Mengawasi Proses} Belajar Anak Di Rumah Pada Masa Pandemi Covid-19 di Rt 002 Rw 001 Kelurahan Sekayu Kota Semarang

Peran orang tua saat pembelajaran daring sangatlah dibutuhkan oleh siswa dimana ini baru pertama kalinya dalam sistem pendidikan di Indonesia di karenakan pandemi Covid-19, mau tidak mau, siap tidak siap kita harus melaksanakan proses pembelajaran secara daring untuk memutus rantai penularan Covid-19. Dimasa pandemi siswa di haruskan berada di rumah dan tidak lepas dari perhatian orang tua dalam mengawasi proses belajar anak, perhatian adalah kemampuan atau kecakapan pemusatan tenaga jasmani dan rohani dengan dasar kemauan sesuai dengan situasi dan kondisi tertentu, karena adanya dorongan terhadap objek.

Ada beberapa faktor yang mempengaruhi perhatian, diantaranya:

1) Faktor pembawaan

2) Faktor keadaan jasmani dan rohani

3) Faktor keadaan diluar diri

4) Faktor minat

5) Faktor perangsang-perangsang yang kuat

6) Faktor sesuatu yang luar biasa

7) Faktor kemauan.,27

\footnotetext{
${ }^{26}$ Suroto, Sebagai Orang tua siswa, wawancara pada hari Rabu 15 Juli 2020

${ }^{27}$ Prof. A. Ghozali, MA., Ilmu Jiwa Seri Paedagogik, PN. Ganaco, Bandung 1980, hlm.
} 119-120. 
Menurut Undang-Undang Sistem Pendidikan Nasional No. 20 Tahun 2003, Pasal 1, menyatakan bahwa kegiatan belajar mengajar adalah proses interaksi peserta didik dengan pendidik dan sumber belajar pada suatu lingkungan belajar. Proses pembelajaran juga diartikan sebagai suatu proses terjadinya interaksi antara pelajar, pengajar dalam upaya mencapai tujuan pembelajaran, yang berlangsung dalam suatu lokasi tertentu dalam jangka satuan waktu tertentu pula.

Proses belajar mengajar akan senantiasa merupakan proses interaksi antara dua unsur manusiawi, yakni siswa sebagai pihak yang belajar dan guru sebagai pihak yang mengajar, dengan siswa sebagai subyek pokoknya. Interaksi belajar mengajar adalah hubungan aktif dua arah antara pendidik dengan peserta didik dalam suatu kegiatan belajar.

Dari beberapa faktor diatas seperti halnya Faktor keadaan jasmani dan rohani sangat mempengaruhi perhatian, sebagaimana halnya seseorang yang dalam keadaan lelah atau mengalami ketegangan jiwa, perhatian sulit dipusatkan pada suatu aktivitas, ini dapat mempengaruhi perhatian orang tua saat proses belajar. Orang tua yang mendampingi anaknya belajar di masa pandemi covid-19 di Rt.002 Rw.001Kelurahan Sekayu Kota Semarang Seperti yang di sampaikan oleh ketua RT"Orang tua banyak yang belum terbiasa, karna merasa tidak maksimal belajar dari rumah.,"28

Orang tua siswa sudah terbiasa dengan pengawasan guru di sekolah anak-anaknya saat belajar, dan orang tua yang pendidikanya rendah merasa canggung ketika harus meperhatikan anaknya ketika proses belajar daring karena ketika anak bertanya sesuatu hal yang tidak tahu orang tua belum tentu bisa menjawab karena pendidikan dimasa orang tuanya berbeda dengan pendidikan sekarang materi yang di sampaikan sekarang lebih komplek. Pembelajaran daring dan luring perlu menyiapkan beberapa hal: ${ }^{29}$

Siapkan perangkat pembelajaran (buku, alat tulis, dan media lainnya)

\footnotetext{
${ }^{28}$ Edi Suyanto, Sebagai Ketua RT, wawancara pada hari Rabu 15 Juli 2020

${ }^{29}$ Kementrian dan kebudayaan, Bersamahadapikorona. Kemdikbud.Go.Id@Kemendikbud RI
} 
Pastikan peserta didik dapat berkomunikasi dengan lancar dengan guru

1) Ajak orang tua untuk mendukung proses pembelajaran

2) Siapkan tempat di rumah yang cukup nyaman untuk belajar

3) Pahami jadwal pembelajaran serta tujuan pembelajaran

4) Aktif dalam diskusi dengan guru Selesaikan tugas dari guru, ajak diskusi orang tua

5) Mengumpulkan tugas dan foto pembelajaran (jika ada)

6) Sampaikan ke guru atau orangtua jika ada kesulitan saat kegiatan belajar hari ini

7) Tuliskan rencana kegiatan sesudah belajar hari ini

Pembelajaran luring menggunakan buku, modul dan bahan ajar dari lingkungan sekitar : ${ }^{30}$

1) Pra Pembelajaran

a. Siapkan buku atau piranti pembelajaran pembelajaran yang dimiliki di rumah.

b. Peserta didik harus mengetahui metode pembelajaran yang akan dijalani secara mandiri di rumah.

c. Ajak orang tua/wali peserta didik untuk mendukung proses pembelajaran.

d. Peserta didik telah memiliki jadwal pembelajaran dan lembar pemantauan dari guru.

2) Saat pembelajaran:

a. Berdoa sebelum kegiatan.

b. Pahami materi pembelajaran sesuai dengan instruksi dari guru.

c. Ajak diskusi orang tua/wali peserta didik atau orang dewasa yang ada di rumah untuk mem

d. bantu proses belajar. Selesaikan penugasan dari guru.

3) Usai pembelajarn:

a. Tutup dengan doa.

${ }^{30}$ Ibid 
b. Mengisi lembar pemantauan harian.

c. Kumpulkan dokumen tugas (dan foto) pembelajaran hari ini.

d. Dokumen tugas, lembar pemantauan harian disampaikan ke guru setiap akhir minggu atau disesuaikan dengan kondisi peserta didi

Belajar pada dasarnya adalah perubahan tingkah laku berkat adanya pengalaman. ${ }^{31}$ Proses belajar mengajar akan senantiasa merupakan proses interaksi antara dua unsur manusiawi, yakni siswa sebagai pihak yang belajar dan guru sebagai pihak yang mengajar, dengan siswa sebagai subyek pokoknya. Interaksi belajar mengajar adalah hubungan aktif dua arah antara pendidik dengan peserta didik dalam suatu kegiatan belajar. Pada masa pandemi Covid-9 anak-anak dapat mengikuti proses belajar dirumah seperti yang di sampaikan orang tua siswa.

"kurang efektif karna belum terbiasa"32

Peran orang tua saat pembelajaran daring: ${ }^{33}$

1. Menyepakati cara untuk berkomunikasi dengan pihak sekolah

2. Mendiskusikan rencana pembelajaran yang inklusif bersama guru sesuai kondisi anak didik

3. Menyiapkan perangkat pembelajaran

4. Memastikan anak didik siap mengikuti pembelajaran

5. Menyiapkan waktu untuk mendukung proses pembelajaran daring

6. Mendorong anak agar aktif selama proses pembelajaran

7. Orang tua/ wali memastikan anak mengisi lembar aktivitas sebagai bahan pemantauan belajar harian

8. Mengumpulkan foto lembar aktivitas dan penugasan setiap hari

9. Secara aktif berdiskusi dengan guru terkait tantangan dan kendala yang dihadapi selama proses pembelajaran daring

\footnotetext{
${ }^{31}$ Dr. Nana Sujana, Cara Belajar Siswa Aktif dalam Proses Belajar Mengajar, Sinar Baru Algensindo, Bandung, 2016, h. 5.

${ }_{32}^{32}$ Suroto, Sebagai Orang tua siswa, wawancara pada hari Rabu 15 Juli 2020 @ KemendikbudRI Kementrian dan kebudayaan, Bersamahadapikorona. Kemdikbud.Go.Id
} 
10. Memastikan tempat dan fasilitas belajar nyaman

Orang Tua/ Wali peserta didik - Pertimbangan khusus untuk Pembelajaran Luring perlu: ${ }^{34}$

1. Mengambil bahan ajar ke sekolah sesuai dengan waktu yang dijadwalkan

2. Lembar pemantauan aktivitas harian dikumpulkan setiap akhir minggu sekaligus mengambil jadwal dan penugasan untuk minggu berikutnya

Salah satu yang menjadi faktor yang mempengaruhi belajar salah satunya dari tingkat individual memberikan kondisi dimana fungsi-fungsi fisiologis termasuk sistem syaraf dan fungsi otak menjadi berkembang. Dengan berkembangnya fungsi-fungsi otak dan syaraf, hal ini akan menumbuhkan kapasitas mental seseorang tidak hanya itu saja alat belajar daring juga sangat di perlukan seperti lektop atau gadget yang dapat menunjang pembelajaran. Di Rt.002 Rw.001Kelurahan Sekayu Kota Semarang oarang tua mendampingi anak dalam proses belajar dirumah di masa pandemi covid-19. Seperti yang di sampaikan orang tua siswa. Dengan bertatap muka secara langsung. ${ }^{35}$

Jadi peran perhatian orang tua dalam mengawasi proses belajar anak di rumah pada masa pandemi covid-19 di rt 002 rw 001 kelurahan sekayu kota semarang menjadi guru secara otomatis, menemani belajar anak, membantu menjelaskan materi pelajaran kepada anak, memberikan sarana mengakses belajar dari rumah seperti lektop, smart phon dan lainlain, menfasilitasi akses internet.

\footnotetext{
${ }^{34}$ Ibid

${ }^{35}$ Suroto, Sebagai Orang tua siswa, wawancara pada hari Rabu 15 Juli 2020
} 


\section{PENUTUP}

Dari hasil penelitian yang telah penulis laksanakan tentang peran perhatian orang tua terhadap proses belajar anak dari rumah pada masa pandemi covid19 di rt 002 rw 001 Kelurahan Sekayu Kota Semarang, maka penulis menyimpulkan bahwa:

1. Kondisi pandemi Covid-19 di RT 002 RW 001 Kelurahan Sekayu Kota Semarang. Dilihat dari sisi ekonomi tidak begitu berpengaruh tetapi di lihat dari segi pendidikan ini menunjukkan sangat mempengaruhi karena kesiapan dari sekolah maupun dari siswa untuk mengikuti pembelajaran daring.

2. Peran perhatian orang tua dalam mengawasi proses belajar anak di rumah pada masa pandemi Covid-19 di RT 002 RW 001 Kelurahan Sekayu Kota Semarang, orang tua menjadi guru secara otomatis, menemani belajar anak, membantu menjelaskan materi pelajaran kepada anak, memberikan sarana mengakses belajar dari rumah seperti laptop, smartphon dan lain-lain, menfasilitasi akses internet

3. Faktor penghambat dan pendukung dalam terhadap proses belajar anak di rumah pada masa pandemi Covid-19 di RT 002 RW 001 Kelurahan Sekayu Kota Semarang. Faktor penghambat diantaranya: (1) Keterbatasan akses internet atau kuota (2) Tidak memiliki laptop atau gadget (3) Kurangnya Perhatian orang tua (4) Kesulitan dalam memahami pelajaran karena proses belajar daring. Faktor pendukung dalam proses belajar anak di rumah pada masa pandemi covid-19 di rt 002 rw 001 kelurahan sekayu kota semarang di antranya (1) Tersedianya alat belajar daring (2) Adanya minat siswa dalam proses belajar daring (3) Adanya motivasi dari orang tua (4) Kondisi siswa yang sehat 


\section{DAFTAR PUSTAKA}

Annur, Saipul, Metodologi Penelitian Pendidikan, Palembang: Rafiah Press, 2005

Budiningsih, Asri, Belajar Dan Pembelajaran, Jakarta; rineka cipta, 2008

Clifffosrd T. Morgan, Introduction to Psichology, Mg Graw-Hill, Kosakusha Ltd., Tokyo, 2011

Departemen Pendidikan dan Kebudayaan, Kamus Besar Bahasa Indonesia, Balai Pustaka, Jakarta, 2010

Falah, Nurul, Hubungan Perhatian Orangtua Dengan Prestasi Belajar Siswa Kelas IV SD Negeri Golo Yogyakarta Tahun Ajaran 2015/2016, (Skripsi,) Yogyakarta: Fakultas Ilmu Pendidikan Universitas Negeri Yogyakarta, 2016

Ghozali, MA., Ilmu Jiwa Seri Paedagogik, PN. Ganaco, Bandung 1980.

Haerudin, Adinda Cahyani, Nur Sitihanifah, Rizky Nurul Setiani, Siti Nurhayati, Veronika Oktaviana, dan Yuliani Indriani Sitorus, 2020, Peran Orangtua Dalam Membimbing Anak Selama Pembelajaran Di Rumah Sebagai Upaya Memutus Covid-19, Karawang: Jurnal Universitas Singaperbangsa Karawang,

https://www.who.int/indonesia/news/novel-coronavirus/qa-for-public

Hurlock Elizabeth B., Child Development, McGraw-Hill Kogakusha, Tokyo, 2012

Idrus, Muhammad. Metode Penelitian Ilmu Sosial, Jakarta: Erlangga, 2009

Inteleligence studio team, kamus besar bahasa Indonesia, Jakarta:Renika cipta 2018

Kartika, Rismawati, Pengaruh Perhatian Orang Tua dalam Kegiatan Belajar terhadap Hasil Belajar Siswa Kelas IV Sekolah Dasar Daerah Binaan III Kecamatan Kandangserang Kabupaten Pekalongan, (Skripsi), Semarang: Jurusan Pendidikan Guru Sekolah Dasar, Fakultas Ilmu Pendidikan, Universitas Negeri Semarang, 2015

Moloeng, Lexy J., Meodologi Penelitian Kualitatif, Bandung: PT. Remaja Rosdakarya, 2006

Muhadjir, Noeng, Metodologi Penelitian Kualitatif, Yogyakarta: Rake Sarasin, 2016

Paizaluddin dan Ermalinda, Penelitian Tindakan Kelas (Classroom Action Research), Bandung: Alfabeta, 2013

Rizka, Valeza Alsi, Peran Orang Tua Dalam Meningkatkan Prestasi Anak Di Perum Tanjung Raya Permai Kelurahan Pematang Wangi Kecamatan Tanjung Senang Bandar Lampung, (Skripsi), Lampung: Fakultas Dakwah Dan Ilmu Komunikasi Universitas Islam Negeri (Uin) Raden Intan Lampung, 2017

Ruslan, Rosady, Metodologi Penelitian Publik Relation dan Komunikasi, Jakarta: PT. Raja Grafindo Persada, Cet. II, 2004

Sekretaris Jendral Kemendikbud nomer 15 tahun 2020 tentang pedoman penyelenggaraan belajar dari rumah dalam masa darurat penyebaran corona virus disease (Covid-19), Jakarta, 2020

Sholeh, Aziz Abdul dan Abdul, Aziz Abdul Majid, Al-Tarbiyah wa Thuruq al-Tadris, Darul Ma'arif, Mesir, 2009

Siregar, Syofian, Metode Penelitian Kualitatif, Jakarta: Kencana Prenada Media Group, 2013

Siswanto, Victorianus Aries, Strategi dan Langkah-Langkah Penelitian, Yogyakarta: Graha Ilmu, 2012

Soemanto, Wasty, Psikologi Pendidikan, Rineka Cipta, Jakarta, 2010

Sugiono, Metode Penelitian Pendidikan (Pendekatan Kunatitatif, Kualitatif dan R\&D), Bandung: IKAPI, 2006

Sugiyono, Metodologi Penelitian Pendidikan Pendekatan Kuantitatif, Kualitatif dan R\&D, Bandung: Alfabeta, 2009 
Jurnal Pendidikan Agama Islam Universitas Wahid Hasyim

Sujana, Nana, Cara Belajar Siswa Aktif dalam Proses Belajar Mengajar, Sinar Baru Algensindo, Bandung, 2016

Sukmadinata, Nana Syaodih, Metode Penelitian Pendidikan, Bandung: PT. Remaja Rosdakarya, Cet. I, 2005

Suryabrata Sumadi, BA., MA., Ed.S., Ph.D., Psikologi Pendidikan, PT. Raja Grafindo Persada, Jakarta, 2012

Suryabrata, Sumadi, BA., MA., Ed.S.,Ph.d., Psikologi Pendidikan, PT. Raja Grafindo Persada, Jakarta, 2013

Suryabrata, Sumadi, Pengantar Psikologi Pendidikan, Yogyakarta: YPF Psikologi UGM, 2011

Surybrata, Sumadi, Metodologi Penelitian, Jakarta: PT. Raja Grafindo Persada, 2006

Walgito, Bimo, Pengantar Psikologi Umum, Andi Offset, Yogyakarta, 2009 